\title{
PREVALENCE OF CELIAC DISEASE IN CHILDREN WITH EPILEPSY
}

\author{
Camilo VIEIRA' ${ }^{\text {, Izabele JATOBÁ2 }}{ }^{\text {, Marília MATOS }}{ }^{3}$, \\ Daniel DINIZ-SANTOS ${ }^{4}$ and Luciana R. SILVA ${ }^{4}$
}

\begin{abstract}
Context - Neurological symptoms have been well-documented in patients with celiac disease, nevertheless, the presumption of a greater prevalence of epilepsy in celiac patients remains controversial. Objectives - To determine the frequency of celiac disease in children and adolescents with idiopathic or cryptogenic epilepsy. Methods - A cross-sectional study. One hundred pediatric patients with non-symptomatic epilepsy were followed-up at two public pediatric neurology clinics in Salvador, Bahia, Brazil. Screening for celiac disease was performed by serial measurements of IgA anti-transglutaminase and IgA anti-endomysium antibodies, followed by bowel biopsy in positive cases. HLA DQ02 and DQ08 were investigated in seropositive individuals, assessing the type of seizures, the number of antiepileptic drugs used and the presence gastrointestinal symptoms. Results - Three (3.0\%) patients tested anti-tTG-positive, two with normal duodenal mucosa (Marsh 0) and one with intraepithelial infiltrate (Marsh I). No villous atrophy of the duodenal mucosa (Marsh III) celiac disease was found. Two patients tested positive for HLA DQ02; none were DQ08 positive. Conclusion - The present study failed to prove the association between celiac disease and epilepsy.
\end{abstract}

HEADINGS - Celiac disease. Epilepsy. Disabled children.

\section{INTRODUCTION}

Celiac disease is an immune-mediated chronic enteropathy that affects genetically susceptible individuals and is triggered by the ingestion of gluten. The prevalence of celiac disease is similar worldwide and is estimated at around $0.3 \%-1.5 \%$ of the general population $^{(1,21,37,45,49)}$. The classic symptoms of celiac disease are chronic diarrhea, abdominal pain, abdominal distention, low weight, diminished stature, vomiting and constipation; however, many patients have extraintestinal manifestations ${ }^{(6,39,50,52)}$, often with no associated gastrointestinal symptoms.

Histological findings should be interpreted according to the criteria defined by Marsh for the classification of the duodenal mucosa lesion ${ }^{(33,51)}$.

Human leukocyte antigens (HLA) DQ02 or DQ08 are often found in individuals with this disease ${ }^{(27,38)}$, HLA DQ02 being present in 90\%-95\% and HLA DQ08 in 5\%-10\% of individuals with celiac disease. Both allotypes together are present in $98 \%$ of celiac patients ${ }^{(14)}$

Epilepsy is one of the most common neurological disorders, affecting around 50 million individuals worldwide, principally in developing countries ${ }^{(36)}$. In Brazil, the epilepsy prevalence is $1 \%-1.5 \%{ }^{(19)}$. In around $50 \%$ of cases, onset occurs in infancy or ado- lescence. With respect to etiology, epilepsy may be idiopathic, cryptogenic or symptomatic ${ }^{(54)}$.

Neurological complications are estimated to occur in 6\%-10\% of patients with celiac disease $(22,34,40,46,48)$. Numerous cases have already been described of gluten-sensitive patients with a high proportion of neurological symptoms of unknown origin, including cerebellar ataxia, peripheral neuropathy, multifocal encephalopathy, epilepsy, dementia, neuromyelitis optica, muscular hypotonia and delayed motor development ${ }^{(18,22,25,26,28,34,40,46,48,53,55)}$. Some studies published in the literature have attempted to demonstrate an association between celiac disease and epilepsy $(4,7,8,11,12,13,18,30,32,35,42,43,44)$.

Some investigators have already carried out studies on the association between celiac disease and epilepsy. In these studies, the frequency of celiac disease in individuals with epilepsy has ranged from $0.78 \%$ to $9.1 \%$. This variation in findings may be explained by the different methodologies or the differences in the criteria used to select the sample population (Table 1).

Some authors have speculated that mechanisms of metabolic deficiency may represent the principal cause of this association ${ }^{(2,23,30,31)}$. Another theory concerns an immunological origin, since recent studies published in the literature have identified autoimmune pathologies such as diabetes mellitus and thyroiditis

Declared conflict of interest of all authors: none

Research performed at: Departamento de Pediatria Neurológica e Departamento de Gastroenterologia e Hepatologia Pediátrica do Hospital Professor Edgard Santos e Centro Pediátrico Professor Hosanah de Oliveira da Universidade Federal da Bahia, Salvador, BA, Brasil.

${ }_{1}^{1}$ Departamento de Pediatria Neurológica da Universidade Federal da Bahia, Salvador, BA, Brasil; ${ }^{2}$ Faculdade de Medicina, Universidade Federal da Bahia, Salvador, BA, Brasil: ${ }^{3}$ Faculdade de Medicina, Escola Bahiana de Medicina e Saúde Pública, Salvador, BA, Brasil; 4 Departamento de Gastroenterologia e Hepatologia Pediárica, Faculdade de Medicina, Universidade Federal da Bahia, Salvador, BA, Brasil.

Correspondence: Dr. Camilo Vieira. Rua Clara Nunes 32, ap. 1304, Pituba - 41810-425 - Salvador, BA, Brasil. E-mail: camilovieira@uol.com.br 
TABLE 1. Original studies conducted with different methodologies to evaluate the prevalence of celiac disease in epileptic patients

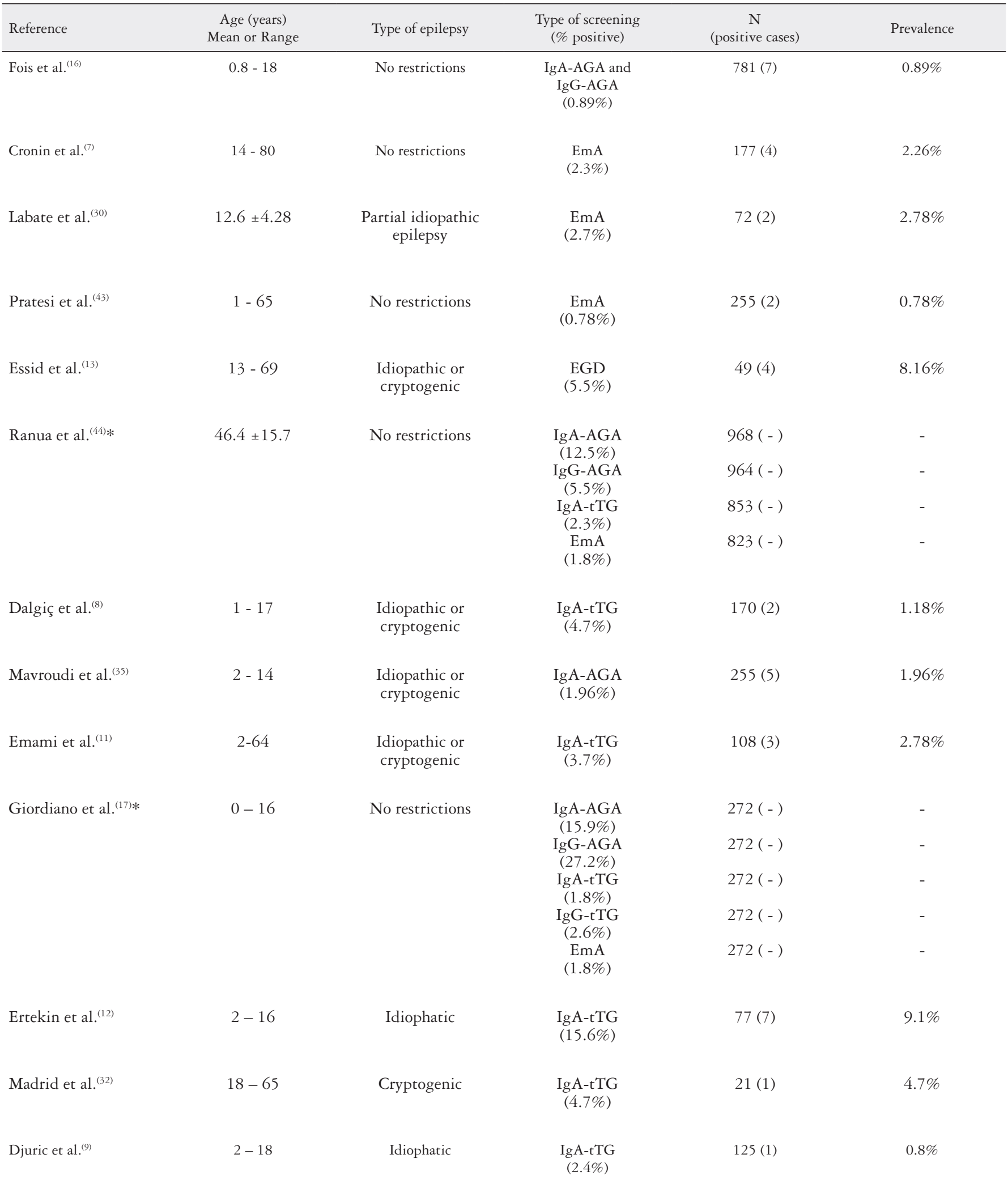

EmA: anti-endomysial antibody; EGD: endoscopy of the upper digestive tract; IgA-AGA: IgA-antigliadin antibody; IgG-AGA: IgG-antigliadin antibody; IgA-tTG IgA: IgA anti-transglutaminase antibody. ${ }^{*}$ Duodenal biopsy was not performed. 
as being associated with celiac disease ${ }^{(50,52)}$. There appears to be no single mechanism, but rather various (nutritional, immunological, neuroendocrine and environmental) mechanisms explaining the possible association between celiac disease and epilepsy.

The objective of the present study was to determine the frequency of celiac disease in children and adolescents with idiopathic or cryptogenic epilepsy.

\section{MATERIAL}

A cross-sectional study was carried out between September 2010 and December 2011 to evaluate 100 pediatric patients with epilepsy, with or without gastrointestinal symptoms, who were undergoing follow-up at the Magalhães Neto pediatric neurology outpatient department of the Professor Edgard Santos Teaching Hospital, Federal University of Bahia and at the outpatient department of the Santo Antonio Hospital of the Obras Sociais Irmã Dulce. Only individuals with cryptogenic or idiopathic epilepsy were included in the study. Prior to inclusion, patients over 18 years of age signed an informed consent form and in the case of patients under 18 years of age this form was signed by the child's mother or legal guardian. All patients underwent at least an electroencephalogram (EEG) and computed tomography or nuclear magnetic resonance of the brain.

\section{METHODS}

The participants responded a questionnaire. Urinalysis was performed and parasitological investigation was conducted in three feces samples. Blood samples were taken to measure total $\operatorname{IgA}$, serum vitamin B12 levels, anti-tissue transglutaminase (anti-tTG) and anti-endomysial (antiEmA) antibodies. Anti-tTG antibodies (IgA, or IgG if a selective IgA deficiency was diagnosed) were investigated using enzyme-linked immunosorbent assay (ELISA) with commercially available diagnostic kits (Quanta Lite tTG, Inova Diagnostics Inc., San Diego, CA, USA). Antiendomysium antibodies were investigated using the indirect immunofluorescence technique with commercially available kits (Inova Diagnostics Inc., San Diego, CA, USA).

All patients identified at serological screening were submitted to endoscopic biopsy of the small intestine, performed by the same endoscopist in all cases. The slides were examined under an optic microscope by a single pathologist, who was experienced in the diagnosis of celiac disease. The duodenal biopsies were classified according to the criteria defined by Marsh $^{(33)}$. The diagnosis of celiac disease was based on the criteria defined by the American Gastroenterological Association $^{(47)}$, with a bowel biopsy of at least Marsh IIIa.

All the patients who screened positive at serology were also submitted to HLA (human leukocyte antigen) typing, since absence of the DQ02 (DQA $1 * 0501 / * 0505$ and DQB $1 * 0201 / * 0202)$ and DQ08 (DQB1*0302) alleles of the HLA virtually excludes the possibility of a diagnosis of celiac disease.
The project was approved by the Internal Review Board of the Santo Antônio Hospital.

The data were analyzed using the SPSS statistical software program, version 14.0. Frequency distributions, center and dispersion measures were calculated. The association between categorical and independent variables was analyzed using Fisher's exact test. Comparison tests between the groups were one-tailed and significance level was established at $P<0.05$ $($ alpha $=0.05)$.

\section{RESULTS}

One hundred children and adolescents completed the questionnaire and had antibody measurements performed. One patient was excluded after a computed tomography brain scan identified an image suggestive of gliosis. Therefore, 99 individuals were included in the study, $61.6 \%$ of whom were male. Age ranged from 1 to 20 years, with a mean of 10.7 \pm 4.2 years.

With respect to the seizure classification, $55.7 \%$ of the participants had predominantly focal seizures, while $14.1 \%$ had predominantly focal seizures with secondary generalization and 30.3\% had generalized seizures. Age at first epileptic seizure ranged from 2 months to 12 years with a mean of 5.3 \pm 3.6 years. Duration of the disease ranged from 2 months to 18 years with a mean of $5.3 \pm 3.8$ years.

The sample was composed predominantly of individuals with easily-controlled epilepsy, $84.8 \%$ of the participants using either no medication at all or one single drug, with only $4 \%$ of patients requiring three or more drugs. The medication used consisted of carbamazepine $(50.5 \%)$, phenobarbital $(27.3 \%)$, sodium valproate $(22.2 \%)$, oxcarbazepine $(9.1 \%)$ and clonazepam $(3.0 \%)$. With respect to compliance with treatment, $83.1 \%$ of the participants reported using the medication regularly and $69.7 \%$ of the sample reported having achieved total control of the epileptic seizures.

At least $19 \%$ of the participants complained of gastrointestinal symptoms, recurrent abdominal pain being the most common symptom (44.4\%) (Table 2). Parasitological tests, performed in 2 or 3 feces samples, and urinalysis were carried out in all participants, and parasites being found in $12.5 \%$ of cases. Of the participants who reported abdominal pain, $56.8 \%(\mathrm{n}=25)$ stated that the pain was moderate to intense. The other gastrointestinal complaints reported were nausea/vomiting $(31.3 \%)$, abdominal distention $(27.3 \%)$,

TABLE 2. Frequency of gastrointestinal symptoms in the study cohort

\begin{tabular}{lcc}
\hline \multirow{2}{*}{ Gastrointestinal symptoms } & \multicolumn{2}{c}{ Frequency } \\
\cline { 2 - 3 } & N & $\%$ \\
\hline Recurrent abdominal pain & 44 & 44.4 \\
Nausea/vomiting & 31 & 31.1 \\
Abdominal distention & 27 & 27.3 \\
Constipation & 24 & 24.2 \\
Recurrent aphthae & 19 & 19.2 \\
Chronic diarrhea & 10 & 10.1 \\
\hline
\end{tabular}


constipation $(24.2 \%)$, recurrent aphthae $(19.2 \%)$ and chronic diarrhea $(10.1 \%)$.

Anti-tTG and anti-EmA antibodies were evaluated in all 99 participants, none of whom were anti-EmA-positive. Three individuals $(3 \%)$ tested positive for anti-tTG antibodies. There were no cases of IgA deficiency. The three anti-tTG-positive participants were referred for endoscopy of the upper digestive tract with duodenal biopsy. Of these, normal duodenal mucosa (Marsh 0) was found in two cases and intraepithelial infiltrate (Marsh I) in one case. No case of villous atrophy of the duodenal mucosa (Marsh III) was found. Two individuals (patients \#1 and \#2) were HLA DQ2-positive. None of the patients who tested positive for anti-tTG antibodies were DQ8-positive. The clinical characteristics of these individuals are shown in Table 3. None of the 99 patients evaluated had cerebral calcifications. There was only one case of vitamin B12 deficiency, which was not, however, associated with anti-tTG positivity.

\section{DISCUSSION}

The different findings in the studies that have evaluated the association between celiac disease and epilepsy may be explained by several factors such as geographical distribution and/or ethnicity, age-group and, principally, by differences in the selection of patients and in the study methodolo-

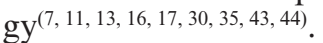

The present sample succeeded in including the principal types of cryptogenic or idiopathic epilepsy in the pediatric age-group ${ }^{(40)}$. The presence of a significantly greater number of individuals in monotherapy, in use of first line drugs and having achieved total control of the seizures shows that the sample was composed of individuals with uncomplicated epilepsy and a positive prognosis.
In the present study, three (3\%) individuals tested positive for anti-tTG antibodies and there were no cases of anti-EmApositivity. A relevant factor that deserves particular emphasis is the use of antibodies for screening epileptic patients for celiac disease. There is no uniformity in the methodology used in the previous studies published on celiac disease and epilepsy. In a recent review on the diagnosis and treatment of celiac disease, the American Gastroenterological Association stated that the highest sensitivity and specificity for the diagnosis of celiac disease is obtained with the IgA-class anti-EmA antibody. The sensitivity and specificity achieved with the $\operatorname{IgA}$ anti-tTG antibody is also considered high: $93.7 \%$ and $95.4 \%$, respectively. The IgA antigliadin antibody (anti-AGA) has the poorest sensitivity (between $85.0 \%$ and $90.0 \%)$ and specificity $(90.0 \%)^{(10,24,47)}$. Up to the present time, no consensus has yet been reached regarding which antibody to use in screening for celiac disease in epileptic patients or whether this test should be performed as routine.

Dalgiç et al.$^{(8)}$ and Emami et al. ${ }^{(1)}$ used IgA anti-tTG, an antibody with high sensitivity, to screen patients for biopsy. Both Cronin ${ }^{(7)}$ and Pratesi ${ }^{(43)}$ found celiac disease in $100 \%$ of EmA-positive epileptic patients, confirming the high specificity of this marker, as already described in the literature ${ }^{(23)}$.

Mavroudi et al. ${ }^{(35)}$ used the anti-AGA antibody to screen for biopsy and investigated the presence of other antibodies in 255 children. The use of this poorly sensitive and poorly specific marker may have underestimated the patients who should have been assessed by endoscopy. Biopsy revealed Marsh III in two individuals, confirming the diagnosis of atrophic celiac disease. In both cases, the patients were antitTg-positive and EmA-negative. The other three participants were diagnosed as Marsh I at biopsy and were also considered by the investigators to have celiac disease, although histology was incompatible with a definitive diagnosis of celiac disease

TABLE 3. Clinical and demographic profile of the epileptic patients testing positive for anti-tTG antibody

\begin{tabular}{llll}
\hline & Patient 1 & Patient 2 & Patient 3 \\
\hline Age & 12.0 years & 2.4 years & 5.9 years \\
Gender & Female & Female & Female \\
Type of seizure & Focal with motor symptoms & Focal with motor symptoms & Focal with motor symptoms \\
Type of therapy & Monotherapy & Monotherapy & Monotherapy \\
Medication used & Oxcarbazepine & Carbamazepine & Carbamazepine \\
Control of the seizures & Yes & Yes & No \\
Brain computed tomography & Normal & Normal & Normal \\
Gastrointestinal symptoms & None & Abdominal pain and distention and chronic diarrhea & Abdominal pain \\
Z score for weight & -0.92 & 1.31 & 1.63 \\
Z score for height & -0.38 & -0.44 & 2.20 \\
Anti-tTG titers & 47.5 & 56.4 & 21.6 \\
Anti-EmA & Negativ & Negative & Negative \\
Vitamin B12 & 408 ng/dL & 660 ng/dL & 770 ng/dL \\
Marsh & 0 & I & 0 \\
HLA DQ2 & Positive & Positive & Negative \\
HLA DQ8 & Negative & Negative & Negative
\end{tabular}




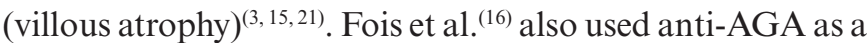
screening method. Despite the low sensitivity and specificity of this antibody, these authors reported that all anti-AGApositive cases had histology compatible with celiac disease; however, the Marsh histology classification was not provided.

Essid et al. ${ }^{(13)}$ performed biopsies in their entire sample of 49 epileptic patients in addition to serology for EmA and AGA. Duodenal lesions were found in four patients, three of whom were classified as Marsh II and 1 as Marsh III (2\%). Although the sample studied by these investigators was small, the fact that serological markers were not investigated as a screening tool and that biopsy was performed directly showed the high prevalence of significant histological lesions identified at duodenal biopsy in epileptic patients. Nevertheless, ethical restrictions make it difficult to reproduce these results.

With the objective of verifying the prevalence of antibodies associated with celiac disease in epileptic patients, Ranua et al. ${ }^{(44)}$ found similar rates of positive serology for anti-AGA, anti-tTG and anti-EmA between participants of a study sample and a control group, with no statistically significant differences in prevalence between the two groups. In Italy, Giordiano et al.(17) compared the frequency of antibodies related to celiac disease (anti-AGA, anti-EmA and anti-tTG) in epileptic children and adolescents and a control group and concluded that there was no difference between the pediatric epileptic population and the healthy controls.

If celiac disease is defined as the presence of a Marsh III duodenal biopsy, i.e. atrophic celiac disease, there would appear to be no increase in the prevalence of this disease in epileptic patients. Some investigators consider a duodenal biopsy finding of Marsh II or even Marsh I to constitute a diagnosis of celiac disease. These cases have been classified as silent ${ }^{(35)}$ or even diagnosed as celiac disease ${ }^{(11,13)}$.

Celiac disease is also classified into the latent and silent forms ${ }^{(47)}$; however, it is impossible to affirm with any certainty whether a patient with a duodenal mucosal lesion and a classification of Marsh I or II will necessarily progress to an atrophic lesion, which characterizes a definitive diagnosis of celiac disease and an indication to initiate treatment with a gluten-free diet. Only monitoring the clinical progression of these patients and following them up will answer this question. Some conditions such as Giardia, cryptosporidium and isosporan infections or inflammatory bowel disease may lead to abnormalities in bowel histology such as intraepithelial infiltrate (Marsh I) or crypt hyperplasia (Marsh II) due to chronic inflammation ${ }^{(5,29,41)}$.

In the present study, perhaps patient \#2 could be considered to have celiac disease in view of the presence of gastrointestinal symptoms, anti-tTG positivity, a histological diagnosis of duodenal mucosa with Marsh I and HLA DQ02 positivity. In this case, the term latent celiac disease would be correct, since there are clinical, immunological and genetic characteristics; however, there are no histologic abnormalities yet; therefore, a definitive diagnosis of celiac disease cannot be made due to the absence of villous atrophy. This patient is being followed up, since the condition is dynamic and should villous atrophy develop, a gluten-free diet must be implemented; however, at the moment, no treatment is indicated. The classification of latent celiac disease may give the idea of a false or questionable association.

If analysis is restricted to studies in which only patients with cryptogenic or idiopathic epilepsy were investigated, an increase in the frequency of celiac disease would be expected, since symptomatic epilepsy, in which the cause of the seizures is well-known, may be considered a confounding factor. Labate et al. ${ }^{(30)}$, Dalgiç et al. ${ }^{(8)}$, Mavroudi et al. ${ }^{(35)}$, Emami et al..$^{(11)}$, Djurić et al. ${ }^{(9)}$, Madrid et al. ${ }^{(33)}$, and Ertekin et al.. ${ }^{(12)}$, limited their samples to individuals with idiopathic or cryptogenic epilepsy. A third study, carried out by Cronin et al..$^{(7)}$ failed to take etiology into consideration in selecting the study sample, but went on to perform an evaluation that restricted the study to idiopathic cases. In the other studies ${ }^{(20,43)}$, findings were compromised due to this methodological drawback, since individuals could have been included in whom epilepsy occurred secondary to an underlying cause.

Comparing the studies in which the prevalence of celiac disease was evaluated in epileptic individuals and in which the type of epilepsy was taken into consideration (symptomatic versus cryptogenic/idiopathic), an increase was found in the prevalence of the disease in studies that failed to restrict the type of epilepsy, although this difference was not statistically significant $(P=0.69)$ (Table 4).

TABLE 4. Cumulative prevalence of atrophic celiac disease in epileptic patients according to the type of epilepsy in the study population

\begin{tabular}{lcc}
\hline Type of epilepsy in the study & $\begin{array}{c}\mathrm{N} \\
\text { (positive cases)* }\end{array}$ & $\begin{array}{c}\text { Prevalence } \\
(\%)^{*}\end{array}$ \\
\hline Idiopathic or cryptogenic & $976(16)$ & $1,64 \%$ \\
No restrictions & $1213(13)$ & $1.07 \%$ \\
Total & $2189(29)$ & $1.32 \%$
\end{tabular}

* Only individuals with Marsh III duodenal biopsy; $P$-value $=0.69$ with $95 \%$ confidence interval.

The type of epileptic seizure in individuals with diagnosed celiac disease in the studies was fairly heterogenous. Of the 20 individuals identified as having celiac disease, 4 had generalized tonic-clonic seizures, 13 had partial epilepsy, 1 had myoclonic epilepsy, 1 had mesial temporal sclerosis and 1 had Lennox-Gastaut syndrome. In one of the studies, no description was provided of the type of epilepsy. Therefore, there are no consistent data that support an association between celiac disease and any particular type of epileptic seizure.

HLA measurement was not performed in any of the previous studies evaluated. The DQ02 and DQ08 allotypes are often found in celiac patients ${ }^{(19,36)}$. In this study, two patients tested positive for HLA DQ02. When neither HLA DQ02 nor DQ08 is found in an individual with positive antibodies for celiac disease, diagnosis of celiac disease in a case classified as Marsh I or II is practically excluded. 


\section{CONCLUSION}

Although epilepsy is considered in the international literature as a condition associated with celiac disease or an extraintestinal manifestation of this disease, the present study has failed to confirm this association. No case of atrophic celiac disease was found in this study, despite the use of a homogenous sample and a rigorous screening for celiac disease in this study.

The use of anti-tTG and anti-EmA as screening tests, followed by a duodenal biopsy in positive cases, may represent methodology that would succeed in covering the majority of individuals with celiac disease. Another option would be to use anti-tTG measurement as the initial screening test followed by anti-EmA only in those cases that tested positive for anti-tTG, with a duodenal biopsy being performed only in cases in which the two antibodies were positive, thus avoiding unnecessary biopsies in individuals in whom only anti-tTG was positive.
Atrophic celiac disease (Marsh III), cannot, up to the present moment, be related to epilepsy. Evaluation of the cases published up to the present time indicates a prevalence that is similar or only slightly higher than the prevalence in the general population. The definitions of latent or silent celiac disease may explain their affirmation of an association between celiac disease and epilepsy, which up to that point was accepted in the international literature. Investigating HLA DQ2 and DQ8 in individuals with Marsh I or II constitutes an important tool for identifying those who are genetically predisposed and who may progress to the atrophic form of celiac disease.

Standardization of the methodology for the investigation of celiac disease in epileptic individuals in the form of multicenter studies with specific populations may help clarify in the future whether an association really exists between celiac disease and epilepsy.

Vieira C, Jatobá I, Matos M, Diniz-Santos D, Silva LR. Prevalência de doença celíaca em crianças com epilepsia. Arq Gastroenterol. 2013,50(4):290-6. RESUMO - Contexto - Os sintomas neurológicos têm sido bem documentados em pacientes com doença celíaca, no entanto, a presunção de uma maior prevalência de epilepsia em pacientes celíacos permanece controverso. Objetivos - Determinar a frequência de Doença Celíaca em crianças e adolescentes portadores de epilepsia idiopática ou criptogênica. Métodos - Estudo transversal. Cem pacientes pediátricos com epilepsia não-sintomática foram acompanhados em dois ambulatórios públicos de neurologia pediátrica em Salvador, Bahia, Brasil. Triagem para doença celíaca foi feita por dosagem sérica de IgA anti-transglutaminase e anti-endomísio IgA, seguido por biópsia de intestino nos casos positivos. HLA DQ02 e DQ08 foram investigadas em indivíduos soropositivos, avaliando o tipo de crise epiléptica, o número de medicamentos anti-epilépticos utilizados e a presença de sintomas gastrointestinais. Resultados - Três (3,0\%) pacientes apresentaram anti-transglutaminase positivo, dois com mucosa normal duodenal (Marsh 0 ) e um com infiltrado intraepitelial (Marsh I). Não foi encontrada atrofia das vilosidades da mucosa do duodeno (Marsh III). Dois deles foram positivos para o HLA DQ02; nenhum foi DQ08 positivo. Conclusão - O presente estudo não conseguiu provar a associação entre doença celíaca e epilepsia.

DESCRITORES - Doença celíaca. Epilepsia. Crianças com deficiência. 


\section{REFERENCES}

1. Bingley PJ, Williams AJ, Norcross AJ, Unsworth DJ, Lock RJ, Ness AR, Jones RW; Avon Longitudinal Study of Parents and Children Study Team. Undiagnosed coeliac disease at age seven: population based prospective birth cohort study. BMJ. 2004;328:322-3.

2. Calvani M Jr, Parisi P, Guaitolini C, Parisi G, Paolone G. Latent coeliac disease in a child with epilepsy, cerebral calcifications, drug-induced systemic lupus erythematosus and intestinal folic acid malabsorption associated with impairment of folic acid transport across the blood-brain barrier. Eur J Pediatr. 2001;160:288-92.

3. Chand N, Mihas AA. Celiac disease: current concepts in diagnosis and treatment J Clin Gastroenterol. 2006;40:3-14

4. Chapman RW, Laidlow JM, Colin-Jones D, Eade OE, Smith CL. Increased prevalence of epilepsy in coeliac disease. Br Med J. 1978;2:250-1

5. Cohen and Powderly, Protozoa: Intestinal Coccidia and Microsporidia, in Infectious Diseases. $2^{\text {a }}$ ed. 2004

6. Collin P, Vilska S, Heinonen PK, Hällström O, Pikkarainen P. Infertility and coeliac disease. Gut. 1996:39:382-4.

7. Cronin CC, Jackson LM, Feighery C, Shanahan F, Abuzakouk M, Ryder DQ, Whelton M, Callaghan N. Coeliac disease and epilepsy. QJM. 1998;91:303-8.

8. Dalgiç B, Dursun I, Serdaroğlu A, Dursun A. Latent and potential celiac disease in epileptic Turkish children. J Child Neurol. 2006;21:6-7.

9. Djurić Z, Nagorni A, Jocić-Jakubi B, Dimić M, Novak M, Milićević R, Radenković G. Celiac disease prevalence in epileptic children from Serbia. Turk J Pediatr. 2012;54:247-50.

10. Donaldson MR, Firth SD, Wimpee H, Leiferman KM, Zone JJ, Horsley W, O'Gorman MA, Jackson WD, Neuhausen SL, Hull CM, Book LS. Correlation of duodenal histology with tissue transglutaminase and endomysial antibody levels in pediatric celiac disease. Clin Gastroenterol Hepatol. 2007;5:567-73.

11. Emami MH, Taheri H, Kohestani S, Chitsaz A, Etemadifar M, Karimi S, Eshag MA, Hashemi M. How frequent is celiac disease among epileptic patients? J Gastrointestin Liver Dis. 2008;17:379-82.

12. Ertekin V, Selimoğlu MA, Tan H, Konak M. Prevalence of celiac disease in a sample of Turkish children with epilepsy. Pediatr Neurol. 2010;42:380.

13. Essid M, Trabelsi K, Jerbi E, Boubaker S, Gorgi Y, Ayed K, Azzouz MM. [Villous atrophy and idiopathic epilepsy]. Tunis Med. 2003;81:270-2.

14. Fasano A. Clinical presentation of celiac disease in the pediatric population. Gastroenterology. 2005;128(4 Suppl 1):S68-73.

15. Fasano A, Catassi C. Coeliac disease in children. Best Pract Res Clin Gastroenterol. 2005;19:467-78

16. Fois A, Vascotto M, Di Bartolo RM, Di Marco V. Celiac disease and epilepsy in pediatric patients. Childs Nerv Syst. 1994;10:450-4.

17. Giordano L, Valotti M, Bosetti A, Accorsi P, Caimi L, Imberti L. Celiac disease-related antibodies in Italian children with epilepsy. Pediatr Neurol. 2009;41:34-6.

18. Gobbi G. Coeliac disease, epilepsy and cerebral calcifications. Brain Dev. 2005; 7:189-200.

19. Gomes MM. Epidemiologia: distribuição, fatores de risco e prognósticos, in Epilepsia editado. 2000, CAM Guerreiro, MM Guerreiro, F Cendes, I LopesCendes: São Paulo. p. 11-21.

20. Greco L, Romino R, Coto I, Di Cosmo N, Percopo S, Maglio M, Paparo F, Gasperi V, Limongelli MG, Cotichini R, D'Agate C, Tinto N, Sacchetti L, Tosi R, Stazi MA. The first large population based twin study of coeliac disease. Gut. 2002;50:624-8

21. Green PH, Rostami K, Marsh MN. Diagnosis of coeliac disease. Best Pract Res Clin Gastroenterol. 2005;19:389-400.

22. Hadjivassiliou M, Grünewald RA, Davies-Jones GA. Gluten sensitivity as a neurological illness. J Neurol Neurosurg Psychiatry. 2002;72:560-3.

23. Hernandez MA, Colina G, Ortigosa L. Epilepsy, cerebral calcifications and clinical or subclinical coeliac disease. Course and follow up with gluten-free diet. Seizure. 1998;7:49-54

24. Hill ID. What are the sensitivity and specificity of serologic tests for celiac disease? Do sensitivity and specificity vary in different populations? Gastroenterology. 2005;128(4 Suppl 1):S25-32.

25. Jacob S, Zarei M, Kenton A, Allroggen H. Gluten sensitivity and neuromyelitis optica: two case reports. J Neurol Neurosurg Psychiatry. 2005;76:1028-30.

26. Jansson U, Johansson C. Down syndrome and celiac disease. J Pediatr Gastroenterol Nutr. 1995;21:443-5.

27. Kaukinen K, Partanen J, Mäki M, Collin P. HLA-DQ typing in the diagnosis of celiac disease. Am J Gastroenterol. 2002;97:695-9.

28. Kieslich M, Errázuriz G, Posselt HG, Moeller-Hartmann W, Zanella F, Boehles H. Brain white-matter lesions in celiac disease: a prospective study of 75 diet-treated patients. Pediatrics. 2001;108:E21.

29. Koot BG, ten Kate FJ, Juffrie M, Rosalina I, Taminiau JJ, Benninga MA. Does Giardia lamblia cause villous atrophy in children?: A retrospective cohort study of the histological abnormalities in giardiasis. J Pediatr Gastroenterol Nutr. 2009; $49: 304-8$
30. Labate A,Gambardella A, Messina D, Tammaro S, Le Piane E, Pirritano D, Cosco C, Doldo P, Mazzei R, Oliveri RL, Bosco D, Zappia M, Valentino P, Aguglia U, Quattrone A. Silent celiac disease in patients with childhood localization-related epilepsies. Epilepsia. 2001;42:1153-5.

31. Lea ME, Harbord M, Sage MR. Bilateral occipital calcification associated with celiac disease, folate deficiency, and epilepsy. AJNR Am J Neuroradiol 1995; 16:1498-500.

32. Madrid S AM, Díaz SM, Hurtado HC, Aguilera OL, Mena UB. Silent celiac disease among 21 patients with cryptogenic epilepsy. Rev Med Chil. 2011;139:587-91.

33. Marsh MN. Gluten, major histocompatibility complex, and the small intestine. A molecular and immunobiologic approach to the spectrum of gluten sensitivity ('celiac sprue'). Gastroenterology. 1992;102:330-54.

34. Martinez-Bermejo A, Polanco I. [Neuropsychological changes in coeliac disease]. Rev Neurol. 2002;34(Suppl 1):S24-33

35. Mavroudi A, Xinias I, Papastavrou T, Karatza E, Fotoulaki M, Panteliadis C, Spiroglou K. Increased prevalence of silent celiac disease among Greek epileptic children. Pediatr Neurol. 2007;36:165-9.

36. Meinardi H, Scott RA, Reis R, Sander JW; ILAE Commission on the Developing World. The treatment gap in epilepsy: the current situation and ways forward. Epilepsia. 2001;42:136-49.

37. Melo SB, Fernandes MI, Peres LC, Troncon LE, Galvão LC. Prevalence and demographic characteristics of celiac disease among blood donors in Ribeirao Preto, State of Sao Paulo, Brazil. Dig Dis Sci. 2006;51:1020-5.

38. Monsuur AJ, de Bakker PI, Zhernakova A, Pinto D, Verduijn W, Romanos J, Auricchio R, Lopez A, van Heel DA, Crusius JB, Wijmenga C. Effective detection of human leukocyte antigen risk alleles in celiac disease using tag single nucleotide polymorphisms. PLoS One. 2008;3:e2270.

39. Mora S, Barera G, Beccio S, Menni L, Proverbio MC, Bianchi C, Chiumello G. A prospective, longitudinal study of the long-term effect of treatment on bone density in children with celiac disease. J Pediatr. 2001;139:516-21.

40. Morris JS, Ajdukiewicz AB, Read AE. Read, Neurological disorders and adult coeliac disease. Gut. 1970;11:549-54.

41. Najarian RM, Hait EJ, Leichtner AM, Glickman JN, Antonioli DA, Goldsmith JD. Clinical significance of colonic intraepithelial lymphocytosis in a pediatric population. Mod Pathol. 2009;22:13-20.

42. Pengiran Tengah DS, Holmes GK, Wills AJ. The prevalence of epilepsy in patients with celiac disease. Epilepsia. 2004;45:1291-3.

43. Pratesi R, Gandolfi L, Martins RC, Tauil PL, Nobrega YK, Teixeira WA. Is the prevalence of celiac disease increased among epileptic patients? Arq Neuropsiquiatr. 2003;61:330-4

44. Ranua J, Luoma K, Auvinen A, Mäki M, Haapala AM, Peltola J, Raitanen J, Isojärvi J.Celiac disease-related antibodies in an epilepsy cohort and matched reference population. Epilepsy Behav. 2005;6:388-92

45. Rewers M. Epidemiology of celiac disease: what are the prevalence, incidence, and progression of celiac disease? Gastroenterology. 2005;128(4 Suppl 1):S47-51

46. Salur L, Uibo O, Talvik I, Justus I, Metsküla K, Talvik T, Uibo R. The high frequency of coeliac disease among children with neurological disorders. Eur J Neurol. 2000;7:707-11

47. Rostom A, Murray JA, Kagnoff MF. American Gastroenterological Association (AGA) Institute technical review on the diagnosis and management of celiac disease. Gastroenterology. 2006;131:1981-2002.

48. Siqueira Neto JI, Costa AC, Magalhães FG, Silva GS. Neurological manifestations of celiac disease. Arq Neuropsiquiatr. 2004;62:969-72.

49. Tatar G, Elsurer R, Simsek H, Balaban YH, Hascelik G, Ozcebe OI, Buyukasik Y, Sokmensuer C. Screening of tissue transglutaminase antibody in healthy blood donors for celiac disease screening in the Turkish population. Dig Dis Sci. 2004;49:1479-84

50. Ventura A, Magazzù G, Greco L. Duration of exposure to gluten and risk for autoimmune disorders in patients with celiac disease. SIGEP Study Group for Autoimmune Disorders in Celiac Disease. Gastroenterology. 1999:17:297-303.

51. Wahab PJ, Meijer JW, Mulder CJ. Histologic follow-up of people with celiac disease on a gluten-free diet: slow and incomplete recovery. Am J Clin Pathol 2002;118:459-63.

52. Westman E, Ambler GR, Royle M, Peat J, Chan A. Children with coeliac disease and insulin dependent diabetes mellitus--growth, diabetes control and dietary intake. J Pediatr Endocrinol Metab. 1999;12:433-42.

53. Wills A, Hovell CJ. Neurological complications of enteric disease. Gut 1996;39:501-4.

54. Yacubian EMT, Cypel S. Fisiopatologia e Formas da Epilepsia, in Neurologia Infantil, Atheneu, Editor. 2005: São Paulo. p. 1105-1125.

55. Zelnik N, Pacht A, Obeid R, Lerner A. Range of neurologic disorders in patients with celiac disease. Pediatrics. 2004:113:1672-6. 